\title{
A new species of Chiroderma (Chiroptera, Phyllostomidae) from Northeastern Brazil
}

\author{
Taddei, VA. ${ }^{\mathrm{a} \dagger}$ and Lim, BK. ${ }^{\mathrm{b} *}$ \\ aPrograma de Pós-Graduação em Meio Ambiente e Desenvolvimento Regional, \\ Universidade para o Desenvolvimento do Estado e da Região do Pantanal - UNIDERP, \\ CP 2153, CEP 79003-010, Campo Grande, MS, Brazil \\ ${ }^{b}$ Department of Natural History, Royal Ontario Museum \\ 100, Queen's Park, Toronto, Ontario M5S 2C6, Canada \\ tin memorian \\ *e-mail: burtonl@rom.on.ca
}

Received October 31, 2008 - Accepted March 18, 2009 - Distributed May 31, 2010

(With 2 figures)

\begin{abstract}
A new species of Chiroderma Peters, 1860 (Chiroptera, Phyllostomidae) from the State of Piauí in Northeastern Brazil is described based on mensural analysis, morphological data and geographical distribution. It is most similar morphologically to $C$. doriae Thomas, 1891 but differentiated by a smaller body size and by differences in cranial traits. In comparison to other members of the genus, the new species can be distinguished by a combination of characters, including size of the body, conspicuousness of facial and median dorsal stripes, ear length, and variation in cranial and dentition traits.
\end{abstract}

Keywords: Chiroptera, Chiroderma, new species, mensural analysis, distribution.

\section{Uma nova espécie de Chiroderma (Chiroptera, Phyllostomidae) do Nordeste do Brasil}

\begin{abstract}
Resumo
Uma nova espécie de Chiroderma (Chiroptera, Phyllostomidae) do Estado do Piauí, Nordeste do Brasil, é descrita baseada em análise morfométrica, dados morfológicos e distribuição geográfica. Ela é morfologicamente similar à C. doriae Thomas, 1891, mas diferenciada desta pelo seu tamanho menor e caracteres cranianos. Em comparação com os outros membros do gênero, a nova espécie pode ser distinguida por uma combinação de caracteres, incluindo tamanho, grau de distinção das listras faciais e médio-dorsais, comprimento da orelha e caracteres crânio-dentários.
\end{abstract}

Palavras-chave: Chiroptera, Chiroderma, nova espécie, morfometria, distribuição.

The big-eyed bats (Chiroderma) are distributed from northwestern Mexico to Southern Brazil and the Antilles (Simmons, 2005; Baker et al., 1994). The genus is presently thought to consist of five species (Simmons, 2005): C. villosum Peters (1860), C. improvisum Baker and Genoways (1976), C. trinitatum Goodwin (1958), C. salvini Dobson (1878) and C. doriae Thomas (1891). The phylogenetic relationships within Chiroderma based on cytochrome $b$ sequence variation were studied by Baker et al. (1994:1326), who concluded that " $C$. salvini's basal position to the other four species of Chiroderma, along with its restricted geograhic range in middle America and western South America, may be explained by $C$. salvini being isolated in Middle America from South American ancestral stock that gave rise to C. villosum, C. improvisum, C. trinitatum, and C. doriae.
Allopatric speciation appears to be the best speciation model to explain the patterns observed in this genus."

Three species of Chiroderma occur in Brazil, with C. trinitatum restricted to the Amazon basin (Mok et al., 1982; Reis and Guillaumet, 1983; Bernard and Fenton, 2002; Bernard and Sampaio, 2008; Tavares et al., 2008), C. villosum is widespread throughout the Brazilian territory, and $C$. doriae is distributed along the eastern coast and in central Brazil to Paraguay (López-González et al., 1998; Tavares et al., 2008). The latter two species overlap in parts of their distribution, but $C$. doriae is larger in size, has trianglular upper inner incisors (conical in C. villosum), pale yellowish brown pelage (grayish in C. villosum), and conspicuous white stripes on the face and back (usually incipient in C. villosum). 


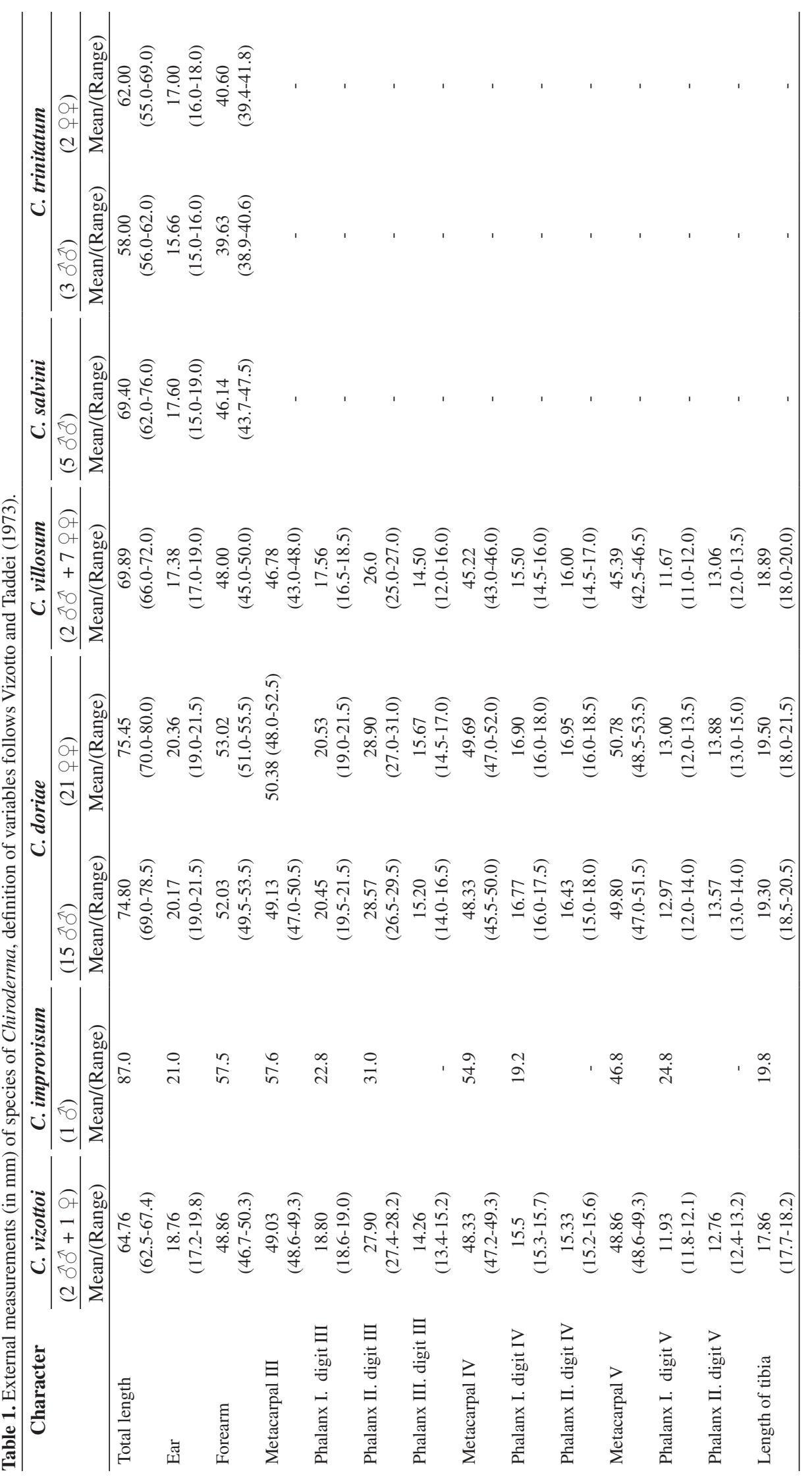




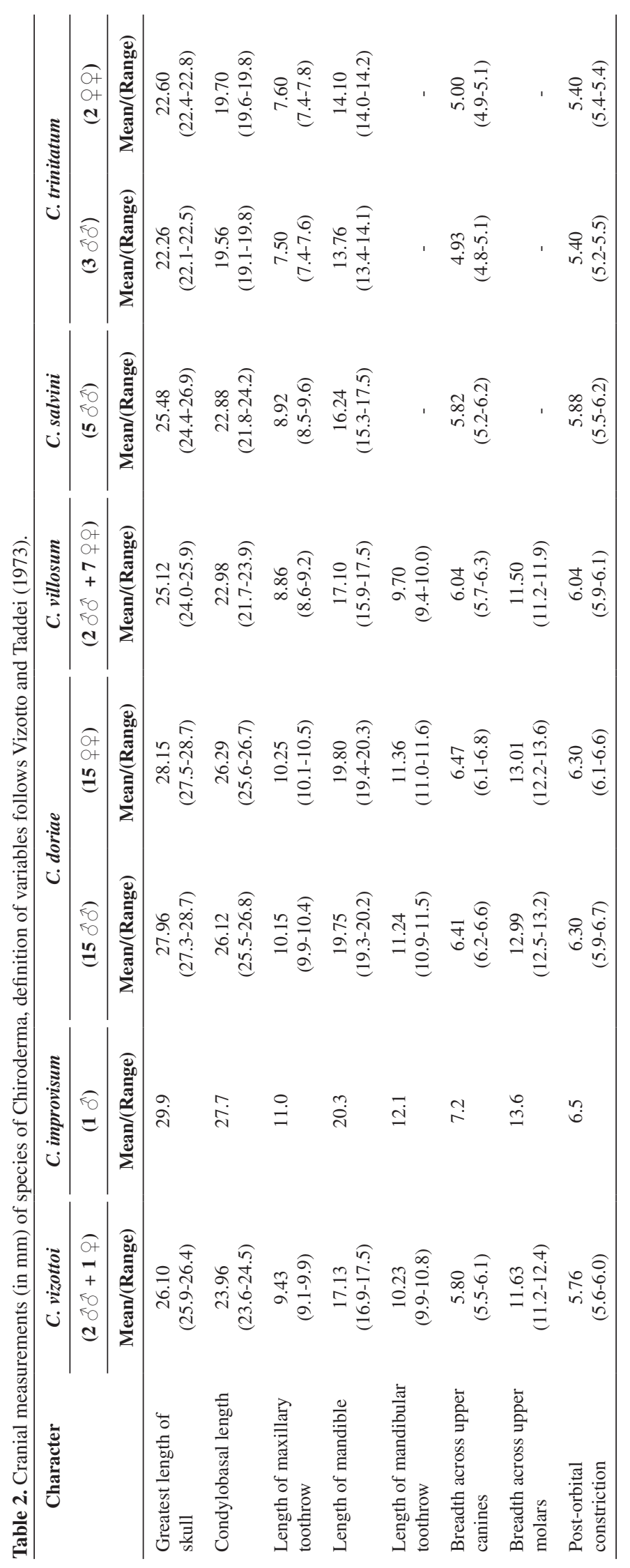


The collections of the Laboratory of Chiropterology of the Universidade Estadual Paulista (DZSJRP) in São José do Rio Preto and the Museum of Zoology of the Universidade de São Paulo (MZUSP) in São Paulo, Brazil have three specimens of Chiroderma from Northeastern Brazil that possess a distinctive combination of both morphological and mensural characters indicating that they belong to a distinct new species, which is described below.

\section{Chiroderma vizottoi, new species}

Holotype: DZSJRP 18054 (field number PI0482), an adult male, alcohol-preserved with skull removed, is deposited at the Laboratory of Chiropterology of the Universidade Estadual Paulista (UNESP) in São José do Rio Preto. The specimen was collected by L.D. Vizotto, A. J. Dumbra, and V. Rodrigues at Teresina (ca. $05^{\circ} 02^{\prime} \mathrm{S}$ and $42^{\circ} 45^{\prime} \mathrm{W}$ ), in the State of Piauí, Brazil. There is no additional data for the specimen, which is in good condition and avalaible for study.

Paratypes: DZSJRP 11460, a subadult male, alcohol-preserved with skull removed, is deposited at the Laboratory of Chiropterology of the Universidade Estadual Paulista (UNESP) in São José do Rio Preto. The specimen was collected by Wilson Uieda in Piracuruca, Parque Nacional de Sete Cidades (ca. 04 05' S and $41^{\circ} 45^{\prime}$ W), State of Piauí, Brazil on 16 January 1976.

MZUSP 33553 (PNSC 55 field number), a lactating adult female, alcohol-preserved with skull removed, is deposited at the Museu de Zoologia da Universidade de São Paulo. The specimen was collected by Alexandre R. Percequillo and Ana Paula Carmignotto in Guaribas, Serra das Confusões, Parque Nacional das Confusões (ca. $09^{\circ} 13^{\prime} \mathrm{S}$ and $43^{\circ} 49^{\prime} \mathrm{W}$ ), State of Piauí, Brazil on 7 October 2000. Both paratypes are in good condition and are available for study.

Geographic distribution: Known from only the State of Piauí in Northeastern Brazil.

Description: A medium-sized species of Chiroderma (forearm: 46.7-50.3; greatest length of skull: 25.9-26.4). All external and cranial measurements for the holotype and paratypes of C. vizottoi are given in Table 1 and Table 2, respectively. Dorsal colouration grayish to light brown; under parts slightly paler than back; well developed facial stripes, the upper pair broad and more prominent, which touch each other in paratype MZUSP 33553 resulting in a large white area over the head; and median dorsal white stripe extending from the shoulders to the base of the interfemoral membrane. Skull, except for being noticeably smaller, is most similar to that of C. doriae; upper inner incisors broader, triangular, obliquely placed, and touching each other at the mid-point in the holotype and MZUSP 33553; upper inner incisors are slightly conical and separated from each other in DZSJRP 11460; upper canines are long; and first lower premolar with a distinct cusp that reaches to half of the height of the second premolar (Figure 1).
Comparison: Chiroderma vizottoi is a mediumsized bat most closely related to $C$. doriae, but substantially smaller both externally and cranially with no overlap in total length, phalanx I - digit IV, greatest length of skull, condylobasal length, length of mandible, length of mandibular toothrow, zygomatic breadth, braincase breadth, mastoid breadth. Also, C. vizottoi has upper canines proportionally longer $(3.2-3.5 \mathrm{~mm}$, whereas in C. doriae they are about $3.0 \mathrm{~mm}$ ) and the breadth across the upper canines is lesser.

Chiroderma vizottoi is readly distinguished from C. improvisum, which is endemic to the Lesser Antilles and the largest species of the genus (forearm: 57.5; greatest length of skull: 29.9), by its smaller size and conspicuous white facial stripes. The new species is similar to $C$. villosum in having proportionally longer canines and greater breadth across the upper canines than in C. doriae. However, C. vizottoi is easily distinguished from $C$. villosum by having conspicuous facial stripes and a distinct median dorsal stripe; broader inner upper incisors, which are positioned obliquely (Figure 2); and first lower premolar with a well-developed cusp that reaches to half of the height of the second premolar. In C. villosum the facial and median dorsal stripes are indistinct, or only faint; the inner upper incisors are slender with a long and simple vertical cusp, which do not approach each other terminally; and the first lower premolars are nearly flat-crowned, without a distinct cusp.

Chiroderma vizottoi can be distinghished from C. salvini by its slightly larger and more robust skull and by the presence of a well-developed cusp on the first lower premolar. Compared to specimens of C. trinitatum, C. vizottoi is, in all respects, noticeably larger with no overlap known to occur in both external and cranial measurements, except for the ear length.

Etymology: The species $C$. vizottoi is named in honour of Professor Luis Dino Vizotto in recognition of his contributions to the systematics of Brazilian bats.

Comments: As presently known, C. vizottoi is endemic to the Caatinga biome. The paratype (MZUSP 33553 ) was caught in a mist net set in low caatinga habitat (Gregorin et al., 2008). There is a recently reported undescribed species of Chiroderma from the Amazonian Forest of Ilha de São Luís in Maranhão State (Cruz et al., 2007) that needs to be examined and compared to C. vizottoi for a better understanding of species boundaries and taxonomy within the genus.

As summarised by Gregorin (1998), C. doriae is found primarily in the Atlantic Forest in northern Paraná, State of São Paulo, Southeastern Minas Gerais, Rio de Janeiro, and, perhaps, Distrito Federal and Mambai districts, both within the Cerrado in the State of Goiás, Brazil. Other Brazilian records are from the States of Santa Catarina, Mato Grosso, Alagoas, and Paraíba (Tavares et al., 2008). There are, however, two disjunct localities from the State of Pernambuco in the Brazilian Northeast (Vizotto and Guerra, 1981). One specimen from Recife (ca. $8^{\circ} 00^{\prime} \mathrm{S}$ and $35^{\circ} 00^{\prime \prime} \mathrm{W}$ ) and another from São Lourenço da Mata 


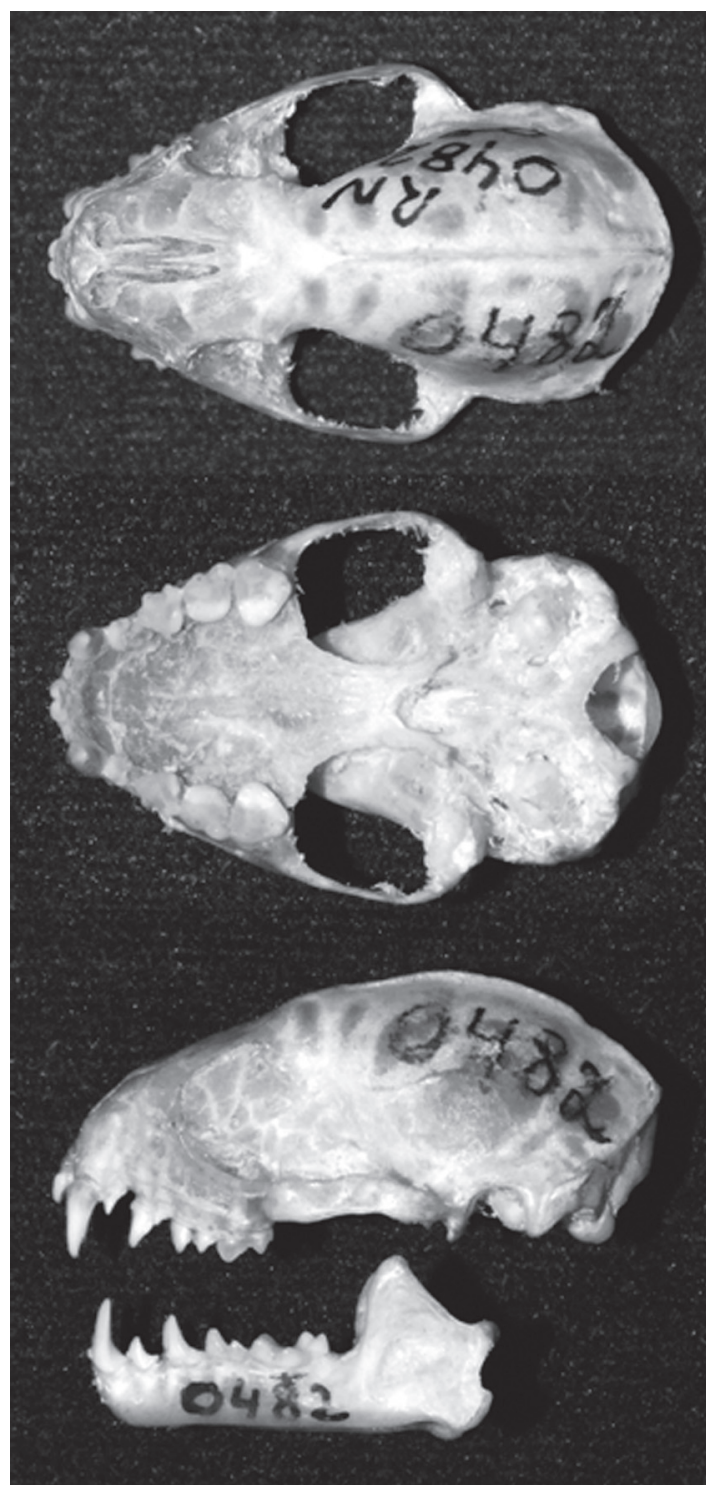

Figure 1. Photograph of the skull of the holotype of Chiroderma vizottoi (DZSJRP 18054). The greatest length of the skull is $25.9 \mathrm{~mm}$.

(ca. $7^{\circ} 58^{\prime} \mathrm{S} ; 35^{\circ} 02^{\prime} \mathrm{W}$ ) are also the nearest localities to the known distributional area of $C$. vizottoi. The external and cranial measurements supplied by Vizotto and Guerra (1981) for the two specimens of $C$. doriae from Northeastern Brazil (total length: 71.0-75.0; forearm: 50.6-51.1; greater length of skull: 28.0-28.0; condylobasal length: 27.0-27.3; maxillary toothrow: 10.1-10.4; zygomatic breadth: 17.8-18.0) fall within the range of variation of the measurements obtained for the populations of this species from Southeastern Brazil (Tables 1 and 2). In addition, $C$. doriae has been reported from the Atlantic Forest of Sergipe State in Northeastern Brazil (Mikalauskas et al., 2006). Of the 13 measurements re-

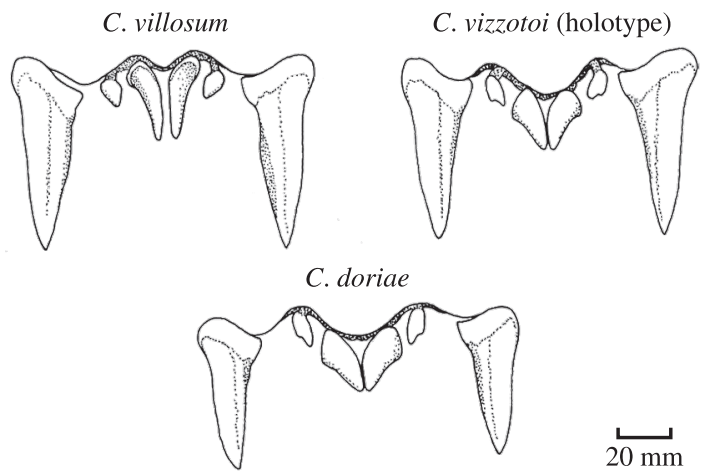

Figure 2. The upper canines and incisors of Chiroderma villosum, C. vizottoi, and C. doriae.

ported in Mikalauskas et al. (2006; including condylobasal of $25.65 \mathrm{~mm}$ ), only three measurements (length of maxillary toothrow, length of mandibular toothrow, and breadth across upper molars) are smaller than $C$. doriae and within the range of $C$. vizottoi. Thus, it seems that $C$. doriae does not noticeably decrease in size towards the northeast, which supports the recognition of $C$. vizottoi as a smaller distinct allopatrically distributed species.

Acknowledgements - We are grateful to Wilson Uieda, Renato Gregorin, and Eliana Morielle Versute for the opportunity to examine specimens, Renato Gregorin and Marcelo Nogueira for commenting on earlier drafts of the manuscript, Renato Gregorin for skull photographs and the figures of the upper incisors, and Fundação de Amparo à Pesquisa do Estado de São Paulo (FAPESP process 98/05075-7) for financial support.

\section{References}

BAKER, RJ., TADDEI, VA., HUDGEONS, JL. and VAN DEN BUSSCHE, RA., 1994. Systematic relationships within Chiroderma (Chiroptera: Phyllostomididae) based on cytochrome $b$ sequence variation. Journal of Mammalogy, vol. 75 , no. 2, p. 321-327.

BERNARD, E. and FENTON, MB., 2002. Species diversity of bats (Chiroptera: Mammalia) in forest fragments, primary forests and savannas in Central Amazonia, Brazil. Canadian Journal of Zoology, vol. 80, no. 6, p. 1124-1140.

BERNARD, E. and SAMPAIO, E., 2008. Morcegos da Amazônia Brasileira. In PACHECO, SM., MARQUES, RV. and ESBÉRARD, CEL. (Eds.). Morcegos no Brasil: biologia, sistemática, ecologia e conservação. Porto Alegre: Armazém Digital. p. 261-274.

CRUZ, LD., MARTÍNEZ, C. and FERNANDES, FR., 2007. Comunidades de morcegos em hábitats de uma Mata Amazônica remanescente na Ilha de São Luís, Maranhão. Acta Amazonica, vol. 37 , no. 4, p. 613-620.

GREGORIN, R., 1998. Extending geographic distribution of Chiroderma doriae Thomas, 1891 (Phyllostomidae, 
Stenodermatinae). Chiroptera Neotropical, vol. 4, no. 2, p. $98-99$

GREGORIN, R., CARMIGNOTTO, AP. and PERCEQUILLO, AR., 2008. Quirópteros do Parque Nacional da Serra das Confusões, Piauí. Chiroptera Neotropical, vol. 14, no. 1, p. 366-383.

LÓPEZ-GONZÁLEZ, C., PRESLEY, SJ., OWEN, RD., WILLIG, MR. and FOX, IG., 1998. Noteworth records of bats (Chiroptera) from Paraguay. Mastozoología Neotropical, vol. 5, no. 1, p. 41-45.

MIKALAUSKAS, JS., MORATELLI, R. and PERACCHI, AL., 2006. Ocurrência de Chiroderma doriae Thomas (Chiroptera, Phyllostomidae) no Estado de Sergipe, Brasil. Revista Brasileira de Zoologia, vol. 23, no. 3, p. 877-878.

MOK, MY., WILSON, DE., LACEY, LA. and LUIZÃO, RCC., 1982. Lista atualizada dos quirópteros da Amazônia brasileira. Acta Amazônica, vol. 12, no. 4, p. 817-823.

REIS, NR. and GUILLAUMET, JL., 1983. Les chauvessouris frugivores de la région de Manaus et leur rôle dans da dissémination des espèces végétales. Revue d'Ecologie La Terre et La Vie, vol. 38, no. 2, p. 147-169.
SIMMONS, NB., 2005. Order Chiroptera. In WILSON, DE. and REEDER, DM. (Eds.). Mammal species of the world: a taxonomic and geographic reference. Baltimore: Johns Hopkins University Press. p. 312-529

TAVARES, VC., GREGORIN, R. and PERACCHI, AL., 2008. A diversidade de morcegos no Brasil: lista atualizada com comentários sobre distribuição e taxonomia. In PACHECO, SM., MARQUES, RV. and ESBÉRARD, CEL. (Eds.). Morcegos no Brasil: biologia, sistemática, ecologia e conservação. Porto Alegre: Armazém Digital. p. 25-60

VIZOTTO, LD. and GUERRA, DQ., 1981. Ocorrência, no nordeste brasileiro, de Chiroderma doriae Thomas, 1891 (Chiroptera-Stenodermatinae). In Resumos do VIII Congresso Brasileiro de Zoologia. Brasília: Universidade de Brasília. p. $132-133$.

VIZOTTO, LD. and TADDEI, VA., 1973. Chave para determinação de quirópteros brasileiros. Revista Faculdade Filosofia Ciências Letras São José do Rio Preto, vol. 1, p. 1-72. (Boletim de Ciências) 